\title{
WASTE MATERIAL AND/OR ENERGY RECOVERY
}

\author{
Åke Erlandsson \\ AB Gustaf Kähr, Nybro \\ Sweden
}

\begin{abstract}
Many far-seeing companies have taken part in the Agenda 21 work for sustainable development.
\end{abstract}

Kährs group has several units being certified in accordance with the ISO 14001 standard and having achieved the EMAS registration.

Waste sorting often is the adaptation of recycling that has been the most important one and that has given all collaborators the opportunity to contribute.

The system of today for material recycling counteracts an efficient use of energy and a market price level of residues.

The energy value is higher than the compensation of collected paper and plastic material.

\section{INTRODUCTION}

During the last few years Sweden has built up a number of recycling systems for various residues with regard to the principle of producer's responsibility. The responsibility for the collection has been changed over from the municipalities to different producer owned companies being financed by charges.

After several years of political discussions about the environmental issues, Swedish industry now thinks of the possibilities on strictly business lines but also of the risks about its environmental profile. Many companies build up management systems for the environmental work according to ISO 14001 or EMAS (Eco Management and Audit Scheme). Waste sorting has often been the most important thing and this has given all collaborators the possibility to contribute in the same way as at home. 
However, the solutions of today within the industry lead to a number of questions.

Does the system of today with regard to material recycling counteract an efficient utilization of energy and a market pricing as to residues?

Shouldn't costs for collecting, packing and receptacles correspond to compensations of material and reduced dump costs?

Doesn't the recycling of materials cause emissions during transports instead of by combustion?

Don't companies and households pay the collection so that the producers get cheaper raw materials?

\section{KÄHRS GROUP}

At Kährs more than 5 million square metres of different parquet floors are produced, multi-layer parquet, solid parquet and veneered wooden floors. Kährs has production sites in four different places in Sweden and Germany. The turnover is approx. 200 million USD. The head office and the management are situated in Nybro, 30 kilometres west of Kalmar.

Kährs belongs to the group of Skanska AB.

The environmental work at Kährs, derives from the vision to use and to make the most of renewable raw materials, with a minimum impact on the environment. The production sites in Nybro and Bodelshausen have achieved the EMAS registration and Nybro and Roosendaal are certified in accordance with the ISO 14001 standard. The remaining sites are building up their environmental systems.

Energy is an important part in the business of the Kährs group. The sites in Nybro, Ljusdal, Bodelshausen and Blomstermåla have their own power plants. In Nybro and Bodelshausen there also is a production of electrical energy.

To get insight in the environmental issues all employees have got training in recycling, at least four hours, with the system conditions from Det Naturliga Steget (The Natural Step) as the basis. Moreover, special trainings have been hold for the management and the key persons at the different plants. ICC's (The International Chamber of Commerce) 16 points for sustainable development have been gone through and have been signed by the management and the key persons at Kährs.

\section{Transformation of energy}

At Kährs' plant in Nybro there are three boilers for solid fuels and one boiler for oil, installed heating effect in total $42 \mathrm{MW}$. When having the available heat requirement internally and on the net of the district heating a turbine of nearly 5 MW is used. During 1996 more than 15000 MWh electricity was produced. 
The boilers are heated with dust and chips from the own sawmill. Grinding dust and chips from the floor factory are pulverized to wood powder for sale to Kalmar Energi $\mathrm{AB}$ and Jönköping Energi $\mathrm{AB}$.

Wood powder has high energy contents, approx. 4,85 MWh/tonne.

The deliveries of wood powder came up to more than $130 \mathrm{GWh}$ during 1996.

Moreover, Nybro delivers about $50 \mathrm{GWh}$ of district heating to Nybro Energi AB.

The amount of consumed and sold bio fuels corresponds to more than 23000 $\mathrm{m}^{3}$ oil.

\section{PRODUCER'S RESPONSIBILITY}

Today Sweden has producer's responsibility according to SFS:1997:185 for packings divided into eight different groups. Half of these groups are based on combustible materials (paper/paperboard, corrugated fibreboard, plastics, and bottles/ "PET")

Through producer's responsibility some producers pay charges to a trade company, REPA. Then this company pays the collection of the material.

Charges and recycling goals in Sweden

\begin{tabular}{|c|c|c|c|c|}
\hline & Charges to REPA & $\begin{array}{l}\text { Goal - } \\
\text { collecting }\end{array}$ & $\begin{array}{l}\text { Goal - } \\
\text { collecting }\end{array}$ & $\begin{array}{l}\text { of which mate- } \\
\text { rial recycling }\end{array}$ \\
\hline Material & $\begin{array}{c}\text { USD/kg } \\
1997\end{array}$ & $\begin{array}{c}\% \\
1997\end{array}$ & $\begin{array}{c}\% \\
2001\end{array}$ & $\begin{array}{c}\% \\
2001\end{array}$ \\
\hline Paper/Paperboard & 0,09 & 30 & 70 & 40 \\
\hline Plastic & 0,020 & 30 & 70 & 40 \\
\hline Corrugated fibreboard & 0,03 & 65 & 65 & 65 \\
\hline Metal & 0,13 & 50 & 70 & 70 \\
\hline
\end{tabular}

The goals for 1997 have been achieved for solid fuels, combustion to a great extent.

The increased goals for paper and plastic up to the year 2001 are to a great extent estimated to be achieved by an increased energy consumption. Consequently, combustion is an accepted recycling.

\section{MATERIAL RECYCLING AT KÄHRS, SOME EXAMPLES}

In connection with building up the EMS, the systems of waste sorting and recycling have been developed at the different plants. All employees have the opportunity and the obligation to sort the waste, both within production, workshops and offices. 
In Bodelshausen they have centrally standing containers for the respective residue. Each department depletes the waste in the right container. Dust from the sawmill is burnt up.

In Ljusdal there is an agreement with a local contractor sorting the different fractions. Combustible waste is used in the district heating plant in the neighbourhood. Wood waste is burnt up at the Ljusdal plant.

\begin{tabular}{||l|c|c|}
\hline In Nybro there are recycling of: & $\begin{array}{c}\text { Amount 1996, } \\
\text { tonnes }\end{array}$ & $\begin{array}{c}\text { Amount quarter 1-2, -97, } \\
\text { tonnes }\end{array}$ \\
\hline \hline Paper/Paperboard & 13,3 & 8,2 \\
\hline Corrugated fibreboard & 14 & 15,3 \\
\hline Board cases & 0 & 3,8 \\
\hline Metal & 210 & 83 \\
\hline Electronic scraps & 0,3 & 0 \\
\hline Cable scraps & 3 & 1,95 \\
\hline Plastic & 57 & 38 \\
\hline Batteries & $0,2(0,024)^{*}$ & \\
\hline Glass & 0,1 & 0,6 \\
\hline \hline
\end{tabular}

${ }^{*} \mathrm{Hg}$ and C.d. batteries

The amount of waste to dump was strongly reduced from -95 to -96 and continues to be reduced during 1997.

The recycling system has to a great extent symbolized the environmental work and created engagement among the staff.

\section{Example plastic}

Plastic is being sorted in three fractions for the compensation of $67 \mathrm{USD} /$ tonne. But then the company has to buy plastic sacks in different colours at the price of $0,35 \mathrm{USD} /$ piece. Each sack contains about 5 kilo plastic. Consequently, the packing costs amount to $67 \mathrm{USD} /$ tonne. The freight costs amount to $67 \mathrm{USD}$ each time or about 1040 USD/year and the container costs for recycling 75 tonnes/year are $800 \mathrm{USD}$, that is to say a cost of about $92 \mathrm{USD} /$ tonne. The costs are not covered, but it is much better than being brought to dump. Bringing the waste to the dump will be much more expensive during 1998 when a tax of 33 USD/tonne is planed and makes the message clear, don't take the waste to the dump. Moreover, there will be more work through sorting in three different plastic fractions. The costs will be approx. 25 USD/tonne higher than the compensation. In spite of the fact that $200 \mathrm{USD} /$ tonne have been paid for the part of the packing plastic being concerned of charges to REPA. The energy value of plastic is high, $10 \mathrm{MWh}$ /tonne of $13 \mathrm{USD} / \mathrm{MWh}$. Consequently, the basic price of 
the sorted plastic being combustible should be about 133 USD/tonne plus the additional costs in order to be profitable to recycle.

\section{Paper towels}

At Kährs, as well as at many other companies, there are intentions to meet the requirements of the system for a working society of recycling.

A producer of paper towels has a return system for his product. Paper towels from all toilets and washrooms are collected in special paper bags, put down in beautiful blue cardboard boxes.

\section{Calculation}

1,200 paper bags of $0,26 \mathrm{USD} /$ piece in order to collect 1,2 tonnes of paper towels consequently cost 307 USD. This is not a big expense item but a high price/kilo. Moreover, there will be internal costs for collecting the paper towels in addition to the "ordinary" waste collection. For this collected material the material company pays 6,7 USD/tonne. The pre-condition is that Kährs bears the costs for the transport of the material, $30 \mathrm{~km}$ to Kalmar.

What is then the energy value for this paper?

With respect to the handling this fuel is not easy, but you can estimate that the contents of bio fuel corresponds to $2,5 \mathrm{MWh} /$ tonne or an energy value of 33 USD/tonne ex combustion plant. Therefore, the costs amount to more than 277 USD/tonne for recycling this paper. No big flow but an evident proof of a system fault.

\section{Bark}

Kährs sawmill in Nybro saws about $80,000 \mathrm{~m}^{3}$ hardwood each year. This gives about 2,000 tonnes of bark being milled and used in the own boiler plant. Moreover, about $1,500 \mathrm{~m}^{3} \mathrm{~s}$ is produced, running the risk of finding also stones and gravel. With regard to the energy it corresponds to about $90 \mathrm{~m}^{3}$ oil. The risk for stones makes the bark expensive to use due to damages in transport equipment before, in and after the boiler.

A great part of the year the moisture contents are so high that the value of the fuel is reduced. Today this bark is used among other things as cover material on dumps. With a future tax on dumped amounts the interest for using the energy contents will increase.

\section{Cardboard waste}

Waste material from a company in the neighbourhood is milled and used as energy fuels in the Nybro plant. About 300 tonnes/year are used. This corresponds to an energy amount of 1,200 MWh. The costs for the buyer are much lower than the alternative to bring the material to the dump. The amount of energy corresponds to about $125 \mathrm{~m}^{3}$ oil/year. 


\section{WHY HAS KÄHRS CHOSEN THOSE SOLUTIONS?}

Recycling is environmentally correct and also with respect to the resources. Limited permissions to burn up residues with producer's responsibility in the plants of the solid fuels.

The legislation of producer's responsibility has resulted in monopoly solutions. With regard to the handling it is difficult to take in part amounts of other kinds of fuels in a working combustion plant.

An uncertain impact on emission levels at various fuel fractions.

The authorities do not want to risk getting an increased number of "destruction plants"

The intention is to make the right things as to the resources and the environment. In total the costs seem to be acceptable, but the calculation as to per tonne of recycled material will lead to the fact that many of us for economical reasons will contest their recycling systems. The examples indicate faults in the system bringing many companies to reduce their intentions with respect to material recycling. Moreover, a working local energy market will be rendered more difficult as to the environment.

If you can use the energy contents without many transports and consumption of packings, this alternative should be preferred. The pre-condition is that the emissions in total are reduced.

Environmental judgings often show that transports constitute a great strain. The energy value often is greater than the compensation given for the recycled material.

The costs for collecting, container rent and transports make recycling of wood and other combustible materials a very expensive business.

\section{Costs and earnings}

Comparison between material recycling and use of energy

\begin{tabular}{|l||c|c|c|}
\hline & $\begin{array}{c}\text { Compensation } \\
\text { USD/tonne }\end{array}$ & $\begin{array}{c}\text { Costs } \\
\text { USD/tonne }\end{array}$ & $\begin{array}{c}\text { Energy value } \\
\text { USD/tonne }\end{array}$ \\
\hline \hline Paper/cardboard & 6,7 & 48 & 33 \\
\hline Plastic - sorted & 67 & 91 & 133 \\
\hline Corrugated cardboard & 10 & 53 & 67 \\
\hline Board cases & 0 & 160 & 33 \\
\hline Paper towels & 6,7 & 267 & 33 \\
\hline
\end{tabular}

The energy value derives from 13,3 USD/MWh. 
For paper/paperboard the costs are higher than the compensation. As the costs of energy use are lower, this is an interesting alternative.

For sorted plastic the compensation nearly covers the costs but the energy value is much higher.

\section{ENERGY SYSTEM ADAPTED TO RECYCLING}

In Sweden there will be a transformation to an energy system adapted to recycling. This will contribute to the fact that the amount of bio fuels will increase by felling more in the forests and by taking more from arable soils. There are several problems about this increased use.

- Do our poor forestlands stand an increased felling?

- Does it be ethically justifiable to burn up food?

- Do we risk getting a new chemically intensive cultivation on a large scale of mono cultures in order to get bio fuels to a sufficient degree?

- Shouldn't residues, that as to energy can be used in an environmentally acceptable way, be locally used if the price of the raw material does not give another signal?

\section{Environmental problems at energy recovery}

Indefinable fuels give uncertainty with respect to emissions of stack gases. Mixed fuels render the combustion more difficult with the risk of a worse efficiency and increased emissions.

Combustion of material containing metals increases the metal contents in the ash being dangerous when returning the ash.

\section{AUTHORS COMMENTS}

The aim of this paper is to show the system faults in the recycling system of materials and also to show the possibilities with respect to the energy use. Due to this fact we need to label and classify materials and products in order to know what can be used in different destruction plants (from heating stoves to heating furnaces and local heating plants or district heating plants).

This makes a local market possible and a local possibility, without unnecessary transports, to use the energy in the goods being purchased.

The producers seeing these labelled products as good raw materials buy them at a price making it interesting to collect. This gives the competition against the use of new raw materials.

This requires some pre-conditions:

Environmentally classified boilers and well educated boiler attendants, private as well as professional.

Advice and directions of a possible mix of different fractions. 
Equipment to make fuels of different materials.

The level of charges for unsorted waste brings about that dump is not an alternative, when recirculation is possible.

However, the main principle always is:

- Recovery, if there is a market.

- Recycling, if there is a market.

- Energy use, if there is a market.

\section{Authority decisions}

Having clear taxes and charges the profitability increases for solutions adapted to recycling. For example, the dump tax is favourable to a correct conduct.

The in due time advertised prohibition 2002 against combustible materials brought to the dump is also a tool for a positive development of the energy use of residues.

Flexibly formed rules for combustion of residues are required.

\section{REFERENCES}

Environmental report for AB Gustaf Kähr 1996

EMAS report for AB Gustaf Kähr 1997

Internal basis of AB Gustaf Kähr, Nybro

SFS:1994:1235, SFS:1997:185 